\title{
Assessment of Social Vulnerability in Malaga Province, Spain: A Comparison of Indicator Standardization Techniques
}

\section{Evaluación de la Vulnerabilidad Social en la Provincial de Málaga, España: Comparación de Técnicas de Estandarización de Indicadores}

\author{
Sumita Gayen \\ sumgay@alum.us.es@0000-0002-5587-9206 \\ Ismael Vallejo-Villalta \\ ivallejo@.us.es@0000-0001-7077-259X
}

Departamento de Geografía Física y Análisis Geográfico Regional, Universidad de Sevilla. C/ Doña María De Padilla, S/N. 41004 Sevilla. Spain.

\author{
Sk. Mafizul Haque
}

mafi_haque@yahoo.co.in@0000-0002-2604-5704

Department of Geography, University of Calcutta 35, B. C. Road. Kolkata. India, Pin-700 019.

\section{INFO ARTÍCULO}

Received: $30-06-2020$

Revised: 27-12-2020

Accepted: 08-01-2021

\section{KEYWORDS}

Social vulnerability

Indicators

Standardization

Natural disasters

\section{PALABRAS CLAVE}

Vulnerabilidad social

Indicadores

Estandarización

Desastres naturales

\begin{abstract}
Hazards are any sort of extreme events that occurred by natural causes, human activities or sometimes both reasons are responsible. Social vulnerability exposes people's condition in hazards. To prevent the loss and damages by hazards, it is necessary to identify vulnerable population of a region by constructing social vulnerability maps of that region. Here in this work, study region is Malaga province, located in southern part of Spain, under the autonomous community of Andalusia. 23 key indicators have been adopted to understand the vulnerability of people in Malaga province at a municipality scale. Three different standardization methodologies (maximum value transformation, $\mathrm{z}$ score transformation and min-max rescaling transformation) have been used to build five vulnerable zones. There exists strong to very strong relationship between the results obtained by using three methodologies. The final result shows that most socio-economically vulnerable municipalities are located mainly in western part of the Malaga province.
\end{abstract}

\section{RESUMEN}

\begin{abstract}
La peligrosidad viene motivada por una serie de fenómenos extremos que pueden ser debidos a causas naturales, a actividades humanas o a una combinación de ambos aspectos. La vulnerabilidad social expresa las condiciones de las personas que pueden ser afectadas por determinados peligros. De cara a la prevención de los daños y pérdidas vinculadas a estos peligros, se hace necesario identificar a la población vulnerable en un territorio determinado a través de la generación de cartografía sobre vulnerabilidad social. En este trabajo, la zona estudiada se corresponde con la provincia de Málaga, que se localiza en la zona sur de España dentro de la Comunidad Autónoma de Andalucía. Un conjunto de 23 indicadores han sido aplicados para analizar la vulnerabilidad de la población de Málaga a nivel municipal. Para ello se han empleado tres técnicas de estandarización (transformación del valor máximo, transformación de las puntuaciones $Z$ y transformación de valores mínimo y máximo) que han permitido la clasificación de los municipios en 5 categorías de
\end{abstract}




\begin{abstract}
vulnerabilidad. Los resultados muestran que existe una importante similitud entre las diferentes técnicas de estandarización elegidas. En todos ellas se detecta que los municipios más vulnerables desde un punto de vista socio-económico se sitúan en la zona occidental de la provincia de Málaga.
\end{abstract}

\title{
1. INTRODUCTION
}

Natural process or phenomena occurring in earth that may constitute a damaging event is known as natural hazard. Almost all countries of the world are affected by natural hazards in each and every year and most of them bring about some sort of natural disaster. Data on natural disasters show an increase both in the number of disasters and in their economic repercussions (Gu, 2019), that it is argued to be mainly linked to an increase in frequency and severity of climate-related hazards associated to climate change (Thomas \& López, 2015; Djalante, 2019). However, natural disasters are dependant not only on natural hazards, as they result from the interaction between these natural hazards and socio-economic conditions of a society; thus, the risk from natural disaster is defined as the probability of this interaction to occur in a particular place (Birkman et al., 2013). In a broad sense, these socio-economic conditions are known as vulnerability.

According to the exposed scheme, natural risk management comprises two basic set of actions. On the one hand, societies have tried to manage and control natural environment, in such a way that extreme events or hazards could be suppressed or reduced both in term of frequency or intensity. Some examples of these measures to manage and control nature include flood control dams and barriers, landslides retaining walls, or breakwater against coastal storms and tsunamis. On the other hand, once societies have assumed that natural hazards cannot be completely prevented, vulnerability reduction measurements are the alternative way to diminish damages and losses from occurring extreme events.

Regardless of the adopted measures (hazard or vulnerability reduction), a common necessary precondition is required that it is related to a depth knowledge of the situation that is to be treated. In the case of hazard reduction measurements this knowledge is about the natural extreme phenomena that usually take place in a particular zone, including some basic parameters related to their magnitude (intensity), temporal patterns (frequency, duration, temporal spacing, speed of onset) and spatial patterns (areal extent and spatial dispersion) (Burton et al., 1978). In the case of vulnerability reduction measurements, the focus of a previous research is the affected society, in order to understand the existence of differences in damages and losses among social groups and along the territory they occupy.

Thus, vulnerability assessment and mapping is an essential stage of natural risk management and it constitutes the research context of this particular study. This paper takes part of wider study for social vulnerability assessment and mapping at different scales, with the aim of gaining knowledge on social vulnerability assessment by the use of several set of data sources, and the application of different statistical and mapping methods. As a first approach, the present study tries to assess social vulnerability for the province of Malaga, from a generic point of view, so it is not focused on a particular hazard. The study makes use of three simple standardization techniques for statistical data simplification in order to compare obtained results, and employs the 103 municipalities of this province as mapping units.

\section{THEORETICAL BACKGROUND}

In the context of risk analysis, United Nations defines vulnerability as "the conditions determined by physical, social, economic and environmental factors or processes that increase the susceptibility of an individual, a community, assets or systems to the impact of hazards" (UN, 2016). Despite this general and clear definition, vulnerability has undergone a long and depth theoretical debate (Birkman et al., 2013). The outcome of this debate is a much more complex concept in which different factors (exposure, fragility, coping capacity, or resilience) and multiple dimensions (physical, social, economic or environmental) could be 
distinguished (Cardona, 2003; Cutter et al., 2003; Wisner et al., 2004; Birkman et al., 2013). As a consequence of this long debate and of the theoretical complexity of the resulted concept, a lack of vulnerability assessment studies was reported, especially in the case of vulnerability mapping (Perles-Roselló, 2010), although in the last decade a great number of this sort of studies has taken place. Apart from the physical vulnerability assessment in which real physical elements (buildings, infrastructures, land-cover patches) are used to evaluate and mapping susceptibility or fragility to hazards (Duzgun et al., 2011; Papathoma-Köhle et al., 2019), most of these aforementioned studies are especially focused on social vulnerability (Beccari, 2016; Ran et al., 2020).

Social vulnerability has been defined as the susceptibility of social groups to potential losses from hazard or resistance and resilience power of a society from hazard (Blaikie et al., 1994), or as a measure of the capability of some elements to withstand events of a certain physical character (Weichselgartner, 2001). Cutter et al. (2003) indicate that it is a pre-existing condition of the population that influences its ability to prepare for, respond to, and recover from hazard events, and Cannon et al. (2003) defined it as the complex set of some characteristics that include a person's initial well-being, livelihood and resilience, self-protection, social-protection, social and political networks and institutions.

Social vulnerability assessment is a process of identifying, quantifying, and analyzing the vulnerability factors in a particular area. Most of these assessment studies are based on statistical data and indicators gathered for different spatial units (mainly, administrative units) at different scales (from national level to census tracts) and these same units are used for mapping purposes (Ran et al., 2020; Contreras et al., 2020). In general terms, the assessment process consists of some basic phases (Beccari, 2016). As a first stage, (i) statistical data are gathered for these spatial units. Indicator selection could be driven according to the type of approach, namely hazard-specific, for those studies focused on a particular hazard (flood, earthquake etc.), or generic, for those others in which social variables are used to measure vulnerability to any hazard (Ran et al., 2020). Other authors (Barrionuevo \& Perles Roselló, 2017; Perles Roselló et al., 2017) indicate the relevance to define the type of vulnerability, namely susceptibility/fragility (vulnerability to the hazard), or resilience (vulnerability to damage). In a second stage, (ii), some data treatments are carried out, including some sort of normalization, reduction, weighting or aggregation techniques. Finally, (iii) vulnerability mapping is accomplished through the classification of the same spatial units. As stated above, a wide range of scales have been used, ranging from global to local/urban studies (Bukvic et al., 2020) and, according to these scales a great variety of spatial units have been employed ranging from countries, usually employed in global studies, to different kind of census units for local and urban analysis. Following are some examples of these varied studies.

As stated above, in the case of global analysis, countries are usually employed as spatial units, and it is quite common that development data are used as vulnerability indicators (André, 2012). At regional scales, different spatial units can be found in vulnerability assessment; some examples are countries, as in the case of Latin America or Asia (CAF, 2014; Hoffmann \& Blecha, 2020), NUTs, used in Europe (EEA, 2018), or river-basins, used in different world regions (Balica et al., 2009). Studies at national level show a great variety of spatial units according to the different administrative units that can be found in each country. In the classical study by Cutter et. al., (2003), Social Vulnerability Index (SoVI) was calculated for all the counties in the United States. In China, the province is frequently used in most of the national scope studies (Yang et al., 2014; Yan \& $\mathrm{Li}$, 2016). National scale assessments in European countries usually employ municipalities or equivalent administrative sub national divisions, as in the case of Norway (Holand et al., 2011), Italy (Frigerio et al., 2018), or Germany (Fekete, 2018). Below the national level, vulnerability assessments are usually carried out within these last mentioned spatial units (municipalities) or in urban environments (Diaz-Sarachaga \& Jato-Espino, 2020). In the case of Spain, census district is a widely employed spatial unit for this type of studies (Morales et al., 2016; Navarro et al., 2020); however, some other more detailed studies have been accomplished, in which cadastral parcels have been used for social vulnerability assessment and mapping (Tascón-González et al., 2020). 


\section{MATERIAL AND METHODS}

\subsection{Study area}

Malaga province is located (Figure 1) in the southern part of the Spain and on the northern coast of the Mediterranean Sea, and is under autonomous community of Andalusia which is the most populous and the second largest in area of the autonomous communities in the country. The area of the province is 7,308 square kilometers. The population of Malaga is 1,641,121 (2018) and population density is 224.53/ sq. km. Malaga has highest population density in Andalusia, and this population density is high mainly in the coastal zone. The province contains 103 municipalities and the capital of the province is Malaga.

From a geological point of view, Malaga province belongs to the Betic System, that forms the most western segment of the Mediterranean alpine orogeny. The relief gains in elevation from the coast to the inner lands, although one of its main characteristics is some sort of segmentation by which mountain ridges and depressions take place (Insua-Arévalo et al., 2012; Gallegos Reina \& Perles Roselló, 2019). Guadalhorce River is the main river of the province and it divided the province into east and west. Guadalmedina, Guadiaro, Genal, Rio Grande, Chillar, Rio Velez, Hozgarganta are other important rivers. Malaga has a Mediterranean climate, with some climate subtypes, as subtropical in the east coastal sector, oceanic mediterranean in the west part of the coast, and continental mediterranean in the inner areas of the province. The maximum temperature in summer often surpass $40^{\circ} \mathrm{C}$, and in winter it is quite soft in the coastal area, although it drops to the freezing point in some places of the higher and inner areas. Annual rainfall is about $500 \mathrm{~mm}$ in average, but heavy rain episodes are frequent and cause severe soil erosion and flood events (Gallegos Reina, 2013).

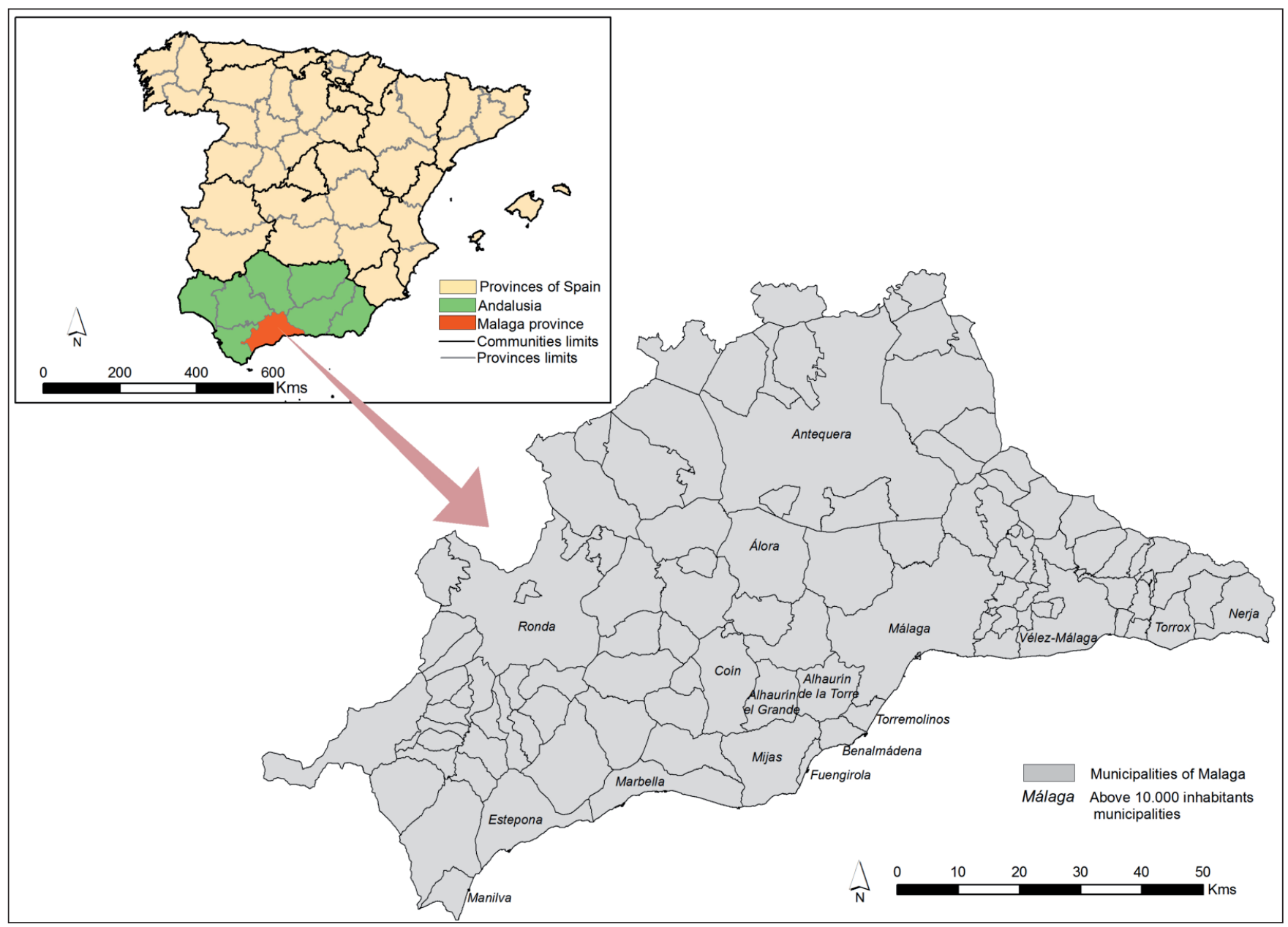

Figure 1. Location map of Malaga Province. Source: Own elaboration. 
River floods are the main hazard in the province of Malaga, especially as flash floods. Apart from the aforementioned heavy rain episodes, some others natural contributing factors are the short and stepped profiles of the typical mediterranean rivers, the proximity to the coast of high mountain ridges and the reduction of the vegetation cover in these mountain areas where main rainfalls take place (Madeca, 2017). As the typical mediterranean paradox, another of the main hazards in Malaga province are droughts, that are naturally caused by long period of rainfall scarcity (Ayuso et al., 2015), although human induced factors are of great relevance (Sánchez \& Del Moral, 2014). Another types of climate related hazards are forest fires, especially during the summer period (Gutiérrez-Hernández et al., 2015), and coastal storms and erosion that frequently take place during autumn and winter months (Prieto et. al., 2017). In the case of geophysical hazards, the province of Malaga is located at the boundary region between Eurasian plate and African plate. So, earthquake is more frequent than the other parts of Spain. The province has suffered earthquakes greater than or equal to maximum intensity VIII (epicenter within Malaga province) in 1494 and 1680, or has been affected by another relevant earthquake with epicenter in the province of Granada (Gayen et al., 2019). Except the mega earthquakes happened in past, every year many minor earthquakes are also happened.

\subsection{Selection of indicators}

An indicator is a measurable variable which represents an associated factor. Pencheon (2007) explained, indicator helps to understand, compare and improve a system. The indicators are not fixed and different authors used different indicators. Selection of indicator depends on the purpose of the study (Weichselgartner, 2001; Tapsell et al., 2005). The assessment of social vulnerability is a key issue of indicator based measurement.

Indicators are not static. It changes with time and space. In same place and time, and working with identical hazard, selection of indicators may be different based on views, analysis criteria etc. of researchers. For identical hazard, indicators can vary from one region to another region though researcher and time are unchanged. It also depends upon country and event-specific characteristics (Kuhlicke et al., 2011).

Data under the different aspects have been collected from secondary source for the detail understanding of social vulnerability. All the data have been collected from Instituto de Estadística y Cartografía de Andalucía (IECA, ) Junta de Andalucía. There are various physical, demographic, economic, social, and health indicators which determine people's level of exposure to vulnerable. Regarding to this, two types of relationship found between indicator and social vulnerability (Table 1). For positive relationship, vulnerability of local people increases with the presence of indicator whereas for negative relationship, vulnerability decreases with increasing value of indicator. Negative value reduces the vulnerability and positive value increases the vulnerability of local people of a region.

\subsection{Description of indicators}

\subsubsection{Distance from capital}

Province's capital is the main functional nuclei of the area which provides all types of essential services, medical supports and emergency recovery treatments. On the other hand, capital city plays an important role for different administrative services which are very crucial during the hazard related policies. Citizen having good economic condition as well as better job opportunities in and around this node and economic growth rate is higher in capital compared to other region. Capital region is well connected by other regions and it provides better relief facilities during the hazards. These all are responsible for declining the unsafe condition of local people and decrease the social vulnerability. 
Table 1. Classifications of indicators.

\begin{tabular}{|c|c|c|c|c|c|}
\hline Aspect & Indicators & Name & $\begin{array}{l}\text { Relationship with } \\
\text { vulnerability }\end{array}$ & $\begin{array}{l}\text { Year of data } \\
\text { source }\end{array}$ & Reference \\
\hline Locational & Distance from capital & DCA & Positive & 2014 & Proposed in this research work \\
\hline \multirow{8}{*}{ Demographic } & Gender & GEN & Positive & 2018 & Müller et al., 2011 \\
\hline & Child population (below 5 years) & CPO & Positive & 2018 & Török, 2018 \\
\hline & Aged population (65 years and above) & APO & Positive & 2018 & Reid et al., 2009 \\
\hline & Dependency ratio & DRA & Positive & 2018 & Kalaycıoğlu et al., 2006 \\
\hline & Single parent nuclei & SPN & Positive & 2011 & Flanagan et al., 2011 \\
\hline & Median age & MAG & Negative & 2018 & Burton et al., 2010 \\
\hline & Foreigners & FOR & Positive & 2011 & Aksha et al., 2019 \\
\hline & Birth rate & BRA & Positive & 2017 & Mavhura et al., 2017 \\
\hline \multirow{5}{*}{ Social } & Population density & PDE & Positive & 2017 & Caliskan et al., 2006 \\
\hline & Large household (5 or more) & $\mathrm{LHO}$ & Positive & 2011 & Ge et al., 2017 \\
\hline & Single and isolated living & SLI & Positive & 2011 & Girasole et al., 2017 \\
\hline & Literacy rate & LRA & Negative & 2001 & Ahmad et al., 2016 \\
\hline & Sport equipments/ 1000 population & SEQ & Negative & 2005 & de Oliveria Mendes, 2009 \\
\hline \multirow{5}{*}{ Economic } & Renters & REN & Positive & 2001 & Armenakis et al., 2017 \\
\hline & Employment rate & ERA & Negative & 2018 & Dwyer et al., 2004 \\
\hline & Population related to agriculture & PRA & Positive & 2009 & Chen et al., 2013 \\
\hline & Average net income (annual in euro) & ANI & Negative & 2016 & Kirby, 2015 \\
\hline & Per capita income (annual in euro) & PCI & Negative & 2016 & Emrich \& Cutter, 2011 \\
\hline \multirow{4}{*}{ Health } & Mortality rate & MRA & Positive & 2017 & Lowe et al., 2013 \\
\hline & Infant mortality rate & IMR & Positive & 2017 & Gayen et al., 2020 \\
\hline & Primary health care/1000 population & $\mathrm{PHC}$ & Negative & 2016 & Fekete, 2009 \\
\hline & Number of pharmacy/1000 population & $\mathrm{NPH}$ & Negative & 2016 & Guillard-Gonçalves et al., 2014 \\
\hline
\end{tabular}

Source: Own elaboration.

\subsubsection{Gender}

Gender is one of the most common determinants of hazard's susceptibility and it has been considered by several researchers for people exposure examination like Dwyer et al. (2004), Tapsell et al. (2005) and Kuhliche et al. (2011). Biologically women section of society is more vulnerable than men specially to overcome the negativity of hazards condition (Dwyer et al., 2004; Morrow, 1999). When any natural hazards strikes then they are busy to protect their children and other family members and take care the injured and sick persons of the family. So, the morbidity and co-morbidity rates of women have been found higher in many hazard events. Women are less educated, so they have few job opportunities and it becomes more during 
post-disaster period. Sometimes they obtained a low status job (Morrow, 1999). Disaster forced women to do work outside the home in an unsafe condition. Economically, women are weaker than men, so they are more vulnerable. Women's vulnerability is also increased due to the loss of family members. It increases more when the head of the family has died and all the responsibilities come on their shoulder. After the hazard women's responsibilities are also expanded at a large extend. Thus, more numbers of women depended family creates high vulnerability in the society.

\subsubsection{Child population}

Children below five years age are the most vulnerable groups in the society during disaster events (Cutter et al., 2003). Children have less physical strength to survive from disasters and they are frequently dependent on others for survival. Children under the five years old are more impacted age group in society due to the presence of abnormal surroundings. They are innocent and they are not able to take their decisions i.e. they are dependent on others for any types of activities support. Children are vulnerable due to lack of their education, previous experience and knowledge. They don't understand what to do during hazardous moments. As children are more closed to women group, their openness towards negativity due to hazards is also wider.

\subsubsection{Aged population}

The older persons have knowledge, but sometimes they are physically disabled and challenged to work for activity. They could also have some hearing and visibility problems. They don't move quickly from one place to another place. They have lack of advance knowledge like communicating others people by internet. Generally elder population has less resistance power of disease. So they are easily affected by waterborne infectious diseases, which are common consequences of many disasters. Which age is more vulnerable? Nobody mentioned any fixed age for it. People above 65, are more vulnerable (Dwyer et al., 2004). Generally, the vulnerability of elders depends on their physical strength. Some old persons are physically stronger than their below aged persons but due to the co-morbidity condition and long term hazardous exposure they are more vulnerable during in society.

\subsubsection{Dependency ratio}

Here dependency ratio is calculated by \% of population under the age of 16 and over 65 years of age along with the people of physically challenged in respect to the population between the ages of 16 and 65 years. Actually it is a ratio between non-working and working population. It shows the pressure of economically productive and working population in a society (Chen et al., 2013). Depended peoples need extra services for their safety and security. Area of high depended population claims extra improvement in the infrastructure sector to minimize the dynamic pressure of hazards event. Higher dependency ratio indicates lower collection of government tax, because working population has a greater responsibility to pay tax. Higher dependency ratio could create labor shortages that can reduce agriculture and industrial production. Lower dependency ratio might be better for pension providers and health care providers but it promotes economic growth of a society. Families with large number of dependents have limited financial opportunities. So during the recovery phase of hazard, they have to face many problems.

\subsubsection{Single parent nuclei}

Child nurturing is very difficult for single parent under any circumstances and parent has sole liability for all activities to support their livelihood. In this case the parent's responsibility is greater as the child is dependent on only one person. All the activities are financially difficult and this family nucleus is socially isolated. During the extreme event condition the single parent try to provide all supports and company to their child. 
Beside the all physical hindrances and community resources it is harder for parent to leave the child at home (Copeland \& Synder, 2011). These all result extra pressure, stress and fatigue on the parent which increase high risk of depression. So, this type of family structure is considered as a root cause of social stress and backwardness for hazards management.

\subsubsection{Median age}

Median age is the midpoint or middle age that divides a population into two equal groups - that is, half the people are younger than this age and half are older. It indicates the average age of a population. Low median age means major part of the population is fertile. Whereas, higher median age signifies declining fertility rates and rising life expectancy with poor equipped to hazards management. Four main aspects are more closely linked with heightened vulnerability of higher median age society and these are i) physical decline including poor health, mobility, sight and hearing, ii) paucity of service provision, support and information, iii) age discrimination which serve to exclude and isolate them, iv) high poverty level which increase low social protection and better opportunities. Thus the high median age reduces the capability towards the preparedness to disasters i.e it is negatively linked with social vulnerability of a region.

\subsubsection{Foreigners}

Generally, foreigners are not well integrated into the society of destination country normally they have limited social and family networks here. New foreigners have lack of connections to the larger community and they feel hesitate to communicate outside their ethnic group for a variety of reasons (Morrow, 1999). They are not well familiar about the local area and also have language barrier, lack of awareness of health services and lack of proper knowledge about their rights and rules. Similarly, they have very little scope to cope up the extreme event results.

\subsubsection{Birth rate}

The birth rate is the expression of total number of live births per 1,000 populations in a year. Along with the increasing numbers of dependent population, high birth rate puts heavy burdens on social infrastructure like health care, essential services, education, land, environment, per capita income, mental supports and public utility services (water, electricity, transport). Infant population requires larger demand on nutritional food without any interruption. High birth rate also indicates large number of infant and child population. Due to the larger exposure to hazards they are most likely to be seriously affected by natural hazards, but they do not able to recover them self without any support. During the recovery phase of hazard, they could also be affected by disease.

\subsubsection{Population density}

Population density is calculated by dividing the population by the geographical land area. Thus the spatial concentration of population in any region is subjected to significant risk of death or damage caused by prominent hazards. Day and night time concentration of population is also controlled the impact of hazards. Like central business district of a city has high probability of life loss during the day time and night time it has very low impacts on society. Positive relationship is found between population density and vulnerability that means high population density incumbents high vulnerability of the society and vice versa. For example, if a large earthquake happens in a large open field, it has little danger. On the other hand, a relatively weak earthquake can pose great risks to human life and economy in densely populated areas. 


\subsubsection{Large household}

Large household increases high chances of vulnerability to hazards. During the critical time this types of household put extra pressure to accumulate huge numbers of recovery resources for members. Similarly, it takes more recovery options to come out from the unusual condition. Large household has numerous residents with low availability of community resources. On the other hand, large household has lower per capita income. If they have few working persons, they cannot able to increase the income to cover the losses by hazards.

\subsubsection{Single and isolated living}

Sometime single and isolated households are economically poor. After hazard they could be suffered with economic problems. The single living persons have also problems during the time of hazard. They may have lack of sufficient human resources to rescue. After the hazard event they could also have the migration problem. If they are injured, no other person is there to take care of them. During or after the hazard they are mentally disturbed also. On that moment they need family support and want some family members to release anxiety and pressure. They can feel loneliness which increases more chances towards long vulnerability.

\subsubsection{Literacy rate}

Education can play an important role to reduce the vulnerability level. A strong negative relationship has been found between education and vulnerability. With proper education one person can learn how to save himself during hazard. Education is related with access to weather forecasts and warnings as well as the types of technologies used to access weather information (Rodríguez et al., 2007). Higher standard of education presents greater chance of employment. Education level can enhance ability to cope with environmental disasters and stress (Wamsler et al., 2012). Educated people can better use the social network which is important tool for emergency planning and preparedness.

\subsubsection{Sport equipments/ 1000 population}

Sport along with the physical exercise helps to develop mental and physical toughness and makes people strong and active. Sport is important for everybody as it reduces stress and enhances mood, it helps to grow the immunity power of human body. It is an excellent way of preventing several chronic diseases such as cardiovascular diseases. Beside these all this facility can encourage youth to involve in the disaster rescue and recovery process. Thus, it has a negative relationship with vulnerability.

\subsubsection{Renters}

Rented peoples don't have their own house. They live in a rent house because they are either transient or they do not have sufficient money to buy their own home (Cutter et al., 2003). Sometimes they have to pay higher rents. They are not able to repair their homes without permission of landlords. Even the rented house became dilapidated condition due to the lack of proper maintenance. Both the indoor and outdoor conditions are found unhygienic. Similarly, after the hazard, rented house becomes too costly and so renters are lack of sufficient shelter options. So, rented people are more vulnerable, compared to people who have their own house.

\subsubsection{Employment rate}

Employed peoples have good standard of living and opportunities of health care. The employee has liable to pay tax which is further invested for the different type infrastructural development. As they have secure job 
opportunity they are able to recover their economic hindrance. The jobless people are more vulnerable to malnutrition and hunger. They have less opportunity of health care. According to Pharr et al. (2012) low opportunity in employment scenario of society tends to show high level of weak mental health which increases social vulnerability.

\subsubsection{Population related to agriculture}

Agriculture is nature dependent economic activity and it requires the superimposition of natural as well as cultural components at the same geographical location. Now-a-days, human control in cultivation process has played a significant role for the productions of agriculture, yet people are helpless to some natural hazards. Many natural acts (like, flood, drought, storms) damage the yield of agriculture within a short span of time. Peoples, who are engaged in agriculture, are more vulnerable as agriculture depends on weather and other hydro-morphological and geological situations (Chen et al., 2013). Crop failure due to extreme environment phenomenon raises the worst situation in the society and people have to wait for long time to escape them from the negative situation.

\subsubsection{Average net income}

It shows the average and overall economic condition of all residences in a specific area. Higher income condition of people improves the education level, health care facilities and quality of life. The comprehensive net income of a society makes all people financially strong for every aspect of economic progress. It improves the base level of quality of life of a region and capability of self-resilience. Thus, the people having better average net income can able to move out quickly from the exposure of negative situation of hazards.

\subsubsection{Per capita income}

Per capita income measures the earning per person in a particular region. Greater per capita income indicates higher standard of living, more occupation opportunities, and instant investment for recovery process. It also indicates the individual capacity of financial strength. So, it has negative relation with the social vulnerability of a particular region.

\subsubsection{Mortality rate}

Mortality rate is usually expressed in number of deaths per 1,000 persons per year in a particular region. Nobel laureate Sen (1998) said that mortality rate is an indicator of economic success and failure. There is a significant relationship between mortality rate and poverty. Poor people are not able to get sufficient and protein rich food. It creates malnutrition, prone to disease and an increased likelihood of dying from the disease. High mortality rate indicates high vulnerability of people.

\subsubsection{Infant mortality rate (IMR)}

IMR is the number of deaths per 1000 live births of children under one year of age. The rate is often used as an indicator to measure the health and well being of a region or a nation. It shows large disparities between developed and developing countries. It also varies across different socio-economic groups. Premature birth is the most important contributor to the IMR. Low birth weight, malnutrition, infectious diseases, poverty are other causes of IMR. High infant mortality rate indicates infants and children are unsafe from different diseases. 


\subsubsection{Primary health care/ 1000 population}

Primary health care plays an important role to recovery the health system. The main role of primary health care is to provide continuous and comprehensive care to the patients. It normally located in the close proximity with a limited distance from home. Thus, the presence of primary health centers indicates better condition of society and it provides the basic treatments during the time of emergency condition. Surgery or critical care of patients is not provided by primary health care but it offers basic treatment to people. In many countries it is a holistic health care system where every people can access medical facilities in low cost or totally free. Primary health care is an essential component of human health and its presence minimizes the social vulnerability.

\subsubsection{Number of pharmacy/ 1000 population}

Pharmacy sells medicine, life saving goods and health care products within a particular belt of society. If there is a drugstore near home, medicine is available within a short period of time and life can save immediate. Thus, the people can arrange medical needs with an emergency requirement which safe the lives and escape a large numbers of people from the vulnerable situation. So, its availability and instant function shows the lowering condition of social vulnerability.

\subsection{Standardization methods}

To calculate the indicators, data have been standardized by using three different methodologies explained hereafter. Standardization is the process of putting different variables from different scale to same scale. It allows comparing scores between different types of variables.

\subsubsection{Maximum value transformation}

In maximum value transformation (Eq. 1 and 2), data are transformed, such that the features lie within a specific range (0-1). It is the ratio between actual value and maximum value of the variable. Higher value means vulnerability is high. Wu et al. (2002), Chakraborty et al. (2005) and Koks et al. (2015) used maximum value transformation standardization method in their study.

For positive relationship,

$$
x=\frac{x_{i}}{\max } \quad \text { (Eq. 1) }
$$

Where, $x i=$ Actual value, $\max =$ Maximum value

For negative relationship,

$$
x=1-\frac{x_{i}}{\max } \quad \text { (Eq. 2) }
$$

Where, $x i=$ Actual value, $\max =$ Maximum value

\subsubsection{Z score transformation}

Z-score is numerical measurements (Eq. 3) that describe the position of a raw score in terms of its distance from the mean when measured in standard deviation. Z-scores may be positive or negative. A positive value indicates the score is above the mean and a negative value signifies it is below the mean. Zero z-score value 
represents that the data point's score is identical to the mean score. Zhang \& Huang (2013), Evans et al. (2014) and Lee (2014) used this standardization method for analysis social vulnerability index.

The formula for calculating a $\mathrm{z}$ score is

$$
x=(q-\mu) / \sigma \quad(\text { Eq. 3) }
$$

Where, $q=$ Actual value, $\mu=$ Mean, $\sigma=$ Standard deviation

For positive relationship, final value adds with total value and for negative relationship final value is deducted from total value.

\subsubsection{Min-max rescaling transformation}

Min-max rescaling is a standardization method (Eq. 4 and 5) that rescales a set of data. In this method, data are transformed to a specific range (0-1). The formula is as follows:

For positive relationship,

$$
x=\frac{x_{i}-\min }{\max -\min } \quad \text { (Eq. 4) }
$$

Where, $x i=$ Actual value, $\min =$ Minimum value, $\max =$ Maximum value

For negative relationship,

$$
x=\frac{\max -x_{i}}{\max -\min } \quad(\text { Eq. 5) }
$$

Where, $\max =$ Maximum value, $x i=$ Actual value, $\min =$ Minimum value

Cutter et al. (2010), Khan \& Salman (2012), Sajjad \& Jain (2014), de Mello Rezende (2016), Tali et al. (2016), Kablan et al. (2017) and Žurovec et al. (2017) used min-max rescaling as a standardization method.

Social vulnerability index (SVI) or final value has been calculated by average of all indicators for each municipality for each standardization method.

\section{RESULTS}

The analysis of SVI has highlighted socio-economic picture of Malaga province. The result for the Malaga province has been analyzed by using all the indicators separately as shown below in Table 2 .

Based on standard deviation score of each methodology adopted, SVI score are grouped into five different categories, hereafter called as vulnerable zones.

- Very low vulnerable zone (<-1.5 std. dev.).

- Low vulnerable zone (-1.5 - -0.50 std. dev.).

- Medium vulnerable zone (-0.50 - $0.50 \mathrm{std}$. dev.).

- High vulnerable zone (0.50 - 1.5 std. dev.).

- Very high vulnerable zone (> $1.5 \mathrm{std}$. dev.).

Figure 2 represents the five different vulnerable zones of Malaga province. It shows that very high vulnerable municipalities are located mainly in western part of Malaga province and least vulnerable municipalities are located in southern part of the province. In some cases, very low and very high municipalities are situated alongside. A large number of municipalities fall under medium vulnerable category. The capital of the province, Malaga is also categorized in medium vulnerable zone. 
Table 2. Indicators and their minimum value, maximum value, mean and standard deviation.

\begin{tabular}{|c|c|c|c|c|c|}
\hline SI. No. & Indicators & $\begin{array}{l}\text { Minimum } \\
\text { Value }\end{array}$ & Maximum Value & Mean & Standard Deviation \\
\hline 1 & Distance from capital & 0 & 153 & 66 & 35.06 \\
\hline 2 & Gender & 42.22 & 51.95 & 49.02 & 1.57 \\
\hline 3 & Child population (below 5 years) & 0.76 & 6.72 & 3.80 & 1.19 \\
\hline 4 & Aged population (65 years and above) & 11.26 & 35.89 & 22.25 & 5.62 \\
\hline 5 & Dependency ratio & 44.15 & 85.19 & 56.59 & 7.91 \\
\hline 6 & Single parent nuclei & 0 & 33.98 & 13.60 & 6.93 \\
\hline 7 & Median age & 37.03 & 53.8 & 45.12 & 3.69 \\
\hline 8 & Foreigners & 1.01 & 55.41 & 11.38 & 11.91 \\
\hline 9 & Birth rate & 0 & 10.65 & 3.66 & 2.01 \\
\hline 10 & Population density & 4.7 & $7,204.71$ & 260.47 & 839.15 \\
\hline 11 & Large household (5 or more) & 0 & 12.85 & 3.75 & 4.18 \\
\hline 12 & Single and isolated living & 3.94 & 22.93 & 10.42 & 3.93 \\
\hline 13 & Literacy rate & 85.4 & 99 & 94.31 & 2.60 \\
\hline 14 & Sport equipments/ 1000 population & 0.95 & 18.39 & 3.94 & 3.13 \\
\hline 15 & Renters & 0 & 9.61 & 3.25 & 2.20 \\
\hline 16 & Employment rate & 67.58 & 91.54 & 77.83 & 4.13 \\
\hline 17 & Population related to agriculture & .01 & 31.38 & 9.03 & 7.04 \\
\hline 18 & Average net income (annual in Euro) & 6060.71 & 21061.51 & 10671.11 & 3190.53 \\
\hline 19 & Per capita income (annual in Euro) & 2042.84 & 9113.01 & 4058.50 & 1326.07 \\
\hline 20 & Mortality rate & 0 & 25.25 & 6.06 & 3.50 \\
\hline 21 & Infant mortality rate & 0 & 166.67 & 3.23 & 18.53 \\
\hline 22 & Primary health care/ 1000 population & 0.03 & 5.85 & 1.03 & 1.29 \\
\hline 23 & Number of pharmacy/ 1000 population & 0 & 5.52 & 0.96 & 1.11 \\
\hline
\end{tabular}

Source: Own elaboration.

Table 3. Very low vulnerable municipalities.

\begin{tabular}{|l|l|}
\hline Standardization Methods & Name of the Municipalities \\
\hline Maximum value transformation & $\begin{array}{l}\text { Atajate, Benalauria, Juzcar, Macharaviaya, Moclinejo, Pujerra, Rincon de la } \\
\text { Victoria, Salares }\end{array}$ \\
\hline Z score transformation & $\begin{array}{l}\text { Alhaurin de la Torre, Atajate, Benahavis, Juzcar, Macharaviaya, Moclinejo, } \\
\text { Rincon de la Victoria }\end{array}$ \\
\hline Min-max rescaling transformation & Atajate, Benahavis, Juzcar, Macharaviaya, Moclinejo, Rincon de la Victoria \\
\hline Source: Own elaboration. &
\end{tabular}

Source: Own elaboration. 


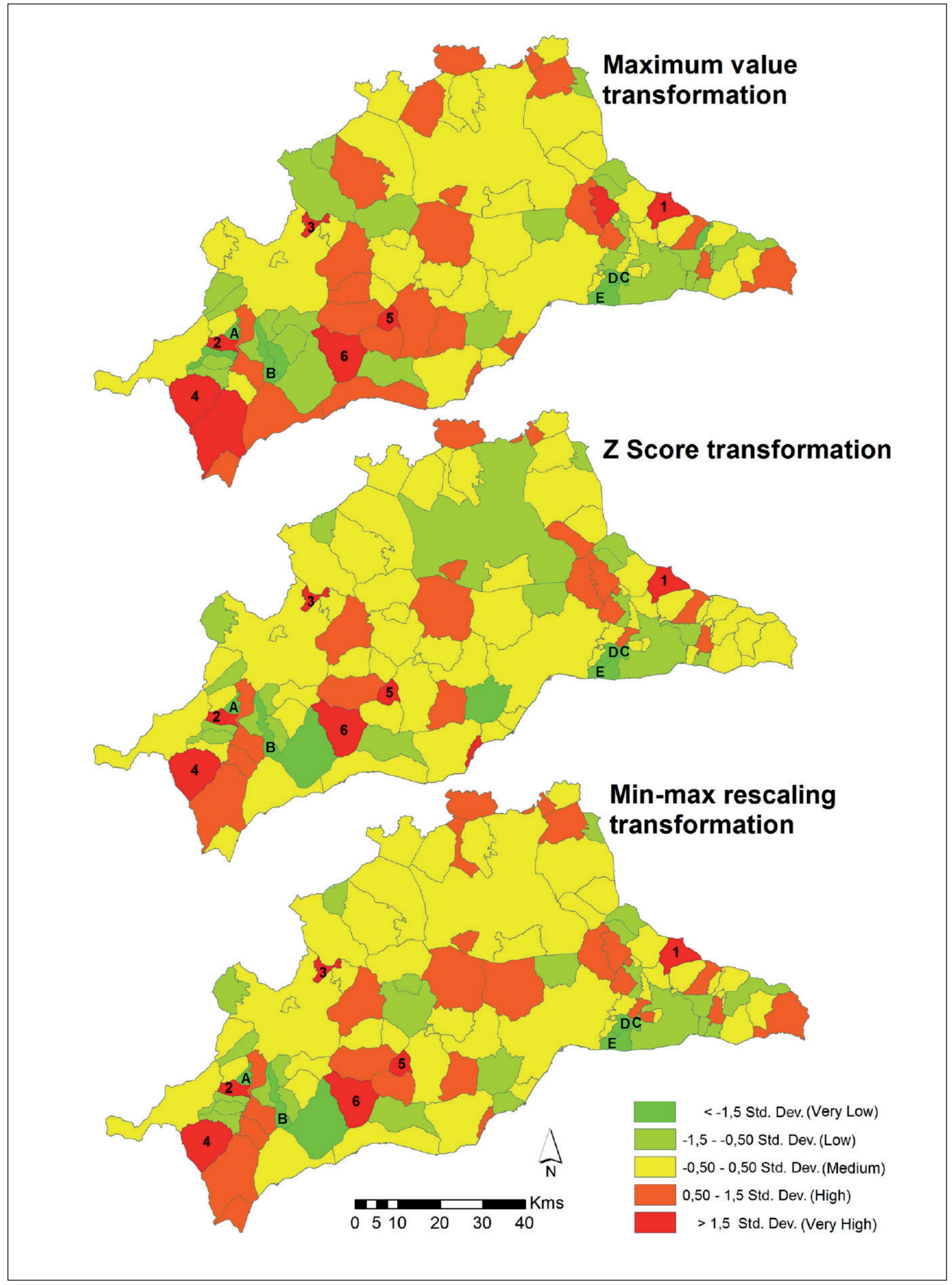

Figure 2. Social vulnerability map of Malaga Province based on three different methodologies. Source: Own elaboration. 
Table 3 shows the very low vulnerable municipalities that obtained from by adopting three different methodologies separately. Atajate (A), Juzcar (B), Macharaviaya (C), Moclinejo (D), Rincon de la Victoria (E) municipalities are common to each methodologies adopted and so categorized in very low vulnerable zone because of low population density, dependency ratio, foreign population, renter, birth rate, mortality rate and infant mortality rate (letters stand to identified municipalities on maps). Also small household and high literate population are reasons of low vulnerability. But all these four municipalities have low employment rate and still falls under very low vulnerable zones. Benahavis municipality is also falls under very low vulnerable zone but common for two types of standardization methods not three. Whereas, Benalauria, Pujerra, Salares, Alhaurin de la Torre municipalities are marked in very low vulnerable category by adopting only one type of standardization method.

Table 4. Very high vulnerable municipalities.

\begin{tabular}{|l|l|}
\hline Standardization Methods & Name of the Municipalities \\
\hline Maximum value transformation & Alcaucin, Benadalid, Casares, Cuevas del Becerro, Gaucin, Guaro, Istan, Riogordo \\
\hline Z score transformation & Alcaucin, Benadalid, Cuevas del Becerro, Fuengirola, Gaucin, Guaro, Istan \\
\hline Min-max rescaling transformation & Alcaucin, Benadalid, Cuevas del Becerro, Gaucin, Guaro, Istan \\
\hline
\end{tabular}

Source: Own elaboration.

The top six municipalities with the highest vulnerability (Table 4) that has been identified in this study are Alcaucin (1), Benadalid (2), Cuevas del Becerro (3), Gaucin (4), Guaro (5), Istan (6) (numbers stand to identified municipalities on maps). Except Alcaucin, other five municipalities located in western part of the province. The main causes of vulnerability in these municipalities are high female population, less sports facilities, moderately high unemployment rate, high dependency ratio, low net income and low income/population. But these municipalities have also low population density, less foreign population and low infant mortality rate (except Istan). Casares, Riogordo, Fuengirola municipalities are also identified as a very high vulnerable category, but are resultant of only employing of one type of standardization method.

Results obtained from the correlation shows (Table 5) both positive and negative relationship between different indicators. Relationship between aged population and median age; between aged population and dependency ratio; between primary health care and pharmacy are positively high. If aged population is more, median age of the population and dependency ratio will be also high. On the other side, high rate of child population reduces the average age of the population. So, high negative relationship has been found between child population and median age of population. \% of agricultural population and average net income has moderately strong negative relationship in between and the same relationship also exists between $\%$ of agricultural population and per capita income.

The correlations between the three methodologies are shown in Table 6. All of the correlations presented are statistically significant.

Pearson's correlation coefficient is the test statistics that measures the strength and statistical relationship between two variables. The result indicates that the strength between maximum value transformation and $z$ score transformation (0.89) is strong. The values of the correlation coefficient are 0.93 (between maximum value transformation and min-max rescaling transformation) and 0.98 (between z score transformation and min-max rescaling transformation) which signify extremely strong relation. 
Table 5. Pearson's Correlation Coefficient between different indicators.

\begin{tabular}{|c|c|c|c|c|c|c|c|c|c|c|c|c|c|c|c|c|c|c|c|c|c|c|c|}
\hline & DCA & GEN & CPO & APO & DRA & SPN & MAG & FOR & BRA & PDE & LHO & SLI & LRA & SEQ & REN & ERA & PRA & ANI & PCI & MRA & IMR & PHC & $\mathrm{NPH}$ \\
\hline DCA & 1 & & & & & & & & & & & & & & & & & & & & & & \\
\hline GEN & -0.12 & 1 & & & & & & & & & & & & & & & & & & & & & \\
\hline CPO & -0.36 & 0.39 & 1 & & & & & & & & & & & & & & & & & & & & \\
\hline APO & 0.36 & -0.35 & -0.74 & 1 & & & & & & & & & & & & & & & & & & & \\
\hline DRA & 0.15 & -0.09 & -0.37 & 0.82 & 1 & & & & & & & & & & & & & & & & & & \\
\hline SPN & 0.25 & 0.22 & 0.18 & -0.11 & -0.11 & 1 & & & & & & & & & & & & & & & & & \\
\hline MAG & 0.41 & -0.40 & -0.80 & 0.97 & 0.69 & -0.08 & 1 & & & & & & & & & & & & & & & & \\
\hline FOR & -0.21 & -0.03 & 0.06 & 0.11 & 0.35 & -0.18 & 0.04 & 1 & & & & & & & & & & & & & & & \\
\hline BRA & -0.29 & 0.14 & 0.48 & -0.47 & -0.36 & -0.04 & -0.45 & -0.01 & 1 & & & & & & & & & & & & & & \\
\hline PDE & -0.27 & 0.30 & 0.18 & -0.21 & -0.15 & 0.09 & -0.22 & 0.22 & 0.09 & 1 & & & & & & & & & & & & & \\
\hline LHO & -0.36 & 0.34 & 0.45 & -0.57 & -0.39 & 0.07 & -0.60 & -0.07 & 0.30 & 0.18 & 1 & & & & & & & & & & & & \\
\hline SLI & 0.31 & -0.26 & -0.39 & 0.61 & 0.43 & 0.05 & 0.65 & 0.09 & -0.35 & -0.05 & -0.52 & 1 & & & & & & & & & & & \\
\hline LRA & -0.27 & 0.18 & 0.14 & -0.33 & -0.29 & -0.03 & -0.34 & 0.26 & 0.13 & 0.29 & 0.21 & -0.23 & 1 & & & & & & & & & & \\
\hline SEQ & 0.44 & -0.24 & -0.30 & 0.41 & 0.21 & 0.18 & 0.47 & 0.11 & -0.33 & -0.05 & -0.43 & 0.55 & -0.06 & 1 & & & & & & & & & \\
\hline REN & 0.09 & 0.21 & -0.02 & -0.19 & -0.19 & 0.15 & -0.15 & -0.03 & 0.14 & 0.11 & 0.19 & -0.15 & 0.21 & -0.14 & 1 & & & & & & & & \\
\hline ERA & -0.06 & 0.14 & 0.34 & -0.26 & -0.09 & 0.16 & -0.30 & 0.15 & 0.01 & 0.12 & 0.08 & -0.19 & 0.10 & -0.04 & -0.04 & 1 & & & & & & & \\
\hline PRA & 0.13 & -0.48 & -0.48 & 0.59 & 0.33 & -0.05 & 0.63 & -0.16 & -0.40 & -0.32 & -0.43 & 0.51 & -0.27 & 0.35 & -0.45 & -0.14 & 1 & & & & & & \\
\hline ANI & -0.27 & 0.49 & 0.55 & -0.67 & -0.41 & 0.22 & -0.67 & 0.27 & 0.28 & 0.46 & 0.42 & -0.42 & 0.43 & -0.20 & 0.38 & 0.41 & -0.68 & 1 & & & & & \\
\hline PCI & -0.24 & 0.53 & 0.35 & -0.56 & -0.37 & 0.24 & -0.57 & 0.00 & 0.25 & 0.38 & 0.45 & -0.45 & 0.44 & -0.35 & 0.48 & 0.28 & -0.61 & 0.81 & 1 & & & & \\
\hline MRA & 0.27 & -0.13 & -0.29 & 0.41 & 0.27 & 0.10 & 0.44 & -0.12 & -0.18 & -0.17 & -0.31 & 0.44 & -0.18 & 0.37 & -0.17 & 0.28 & 0.34 & -0.39 & -0.35 & 1 & & & \\
\hline IMR & 0.00 & 0.04 & 0.04 & -0.08 & -0.08 & 0.05 & -0.08 & -0.01 & -0.40 & -0.01 & 0.28 & -0.07 & -0.02 & 0.01 & 0.00 & 0.15 & -0.07 & 0.10 & 0.08 & -0.02 & 1 & & \\
\hline $\mathrm{PHC}$ & 0.46 & -0.40 & -0.36 & 0.54 & 0.32 & 0.15 & 0.58 & -0.15 & -0.40 & -0.21 & -0.48 & 0.61 & -0.18 & 0.66 & -0.20 & -0.07 & 0.56 & -0.50 & -0.49 & 0.34 & -0.08 & 1 & \\
\hline NPH & 0.45 & -0.27 & -0.28 & 0.51 & 0.38 & 0.27 & 0.53 & -0.11 & -0.34 & -0.15 & -0.43 & 0.62 & -0.28 & 0.61 & -0.17 & 0.02 & 0.48 & -0.40 & -0.44 & 0.37 & -0.07 & 0.85 & 1 \\
\hline
\end{tabular}

Source: Own elaboration.

Table 6. Pearson's correlation coefficient between three methodologies.

\begin{tabular}{|l|c|c|c|}
\hline & Maximum value transformation & Z score transformation & Min-max rescaling transformation \\
\hline Maximum value transformation & 1 & & \\
\hline Z score transformation & 0.89 & 1 & 1 \\
\hline Min-max rescaling transformation & 0.93 & 0.98 & 1 \\
\hline
\end{tabular}

Source: Own elaboration. 


\section{DISCUSSION}

As a first approach, this analysis of social vulnerability in Malaga province has highlighted the present locational, demographic, social, economic, and health condition of the province. This municipality-wise analysis has explained all the indicators adopted and identified different groups of vulnerable municipalities. These groups are very similar regardless of the applied standardization method, as has been shown by correlation coefficients. Equivalent results have been obtained in other studies where the outcomes of different deductive methodologies are very highly correlated with each other (Yoon, 2012).

Main causes of very high vulnerability are mainly low net income and low income/population, high female population, moderately high unemployment rate and high dependency ratio. In a broad sense, similar results are usually obtained by other studies in different contexts (Cutter et al., 2003; Morales et al., 2016; Navarro et al., 2020).

In spite of these acceptable results, among the main aims of this initial research are to detect and outline weaknesses and limitations to be overcome in future works. The following are the most relevant ones.

As general weaknesses of social vulnerability assessments are to examine the validation of obtained vulnerability indicators (Beccari, 2016). In few cases this validation is accomplished by comparison among vulnerability indicators and disaster damages and losses information (Yoon, 2012). In order to develop a similar approach in our context, different data sources should be explored in future research, namely direct information from municipalities, data compiled by civil protection authorities, or by private or public insurance companies (Consorcio de Compensación de Seguros). Also related to data and indicators, future vulnerability studies could be focused on a specific hazard or group of hazards, in such a way as enable some improvement on indicators selection criteria.

Similarly, data reduction and aggregation techniques need to be largely improved. Although in the present study a comparison of normalization methods was accomplished, a very simple aggregation technique was employed and no data weighting or reduction was applied. In the next research steps, principal component analysis (PCA) would be adopted, as one of the most extended and successful methodologies (Contreras et al., 2020).

Municipalities show some advantages mainly related to data gathering, both on socio-economic and disaster damages data. Nevertheless, municipality extent should be very unsuitable if social vulnerability assessments and the resulted maps are to be used for subsequent risk studies by mean of integration of vulnerability and hazard maps. While an increasing spatial detail has been reached in hazard mapping (Muhadi et al., 2020), only some aspects of vulnerability related to characteristics of buildings, infrastructures or land-use patches (Papathoma-Köhle et al., 2019), or related to spatial indicators like accessibility (Barrionuevo \& Perles Roselló, 2017), show comparable levels of spatial resolution. To overcome this gap among social vulnerability and hazard maps, indicators based social vulnerability assessment should look for other types of spatial units as census district or cadastral parcels and buildings (Navarro et al., 2020; Tascón-González et al., 2020).

\section{CONCLUSION}

Natural hazards cause great damages all over the world. Hazard maps can identify hazard prone areas but cannot able to measure the vulnerability of population in any region. Social vulnerability measures the susceptibility of social groups to the impacts of hazards and it is an important tool of hazard risk reduction system. The analysis of social vulnerability in Malaga province has highlighted the present locational, demographic, social, economic and health condition of the province. Key causes of very high vulnerability are mainly economic factors like, high dependency ratio, unemployment rate and low income. To overcome from this vulnerability, vulnerable municipalities need to have more economic activities. This study also investigated spatial patterns of social vulnerability in Malaga province using three different standardization methods. The results obtained from these methodologies are almost same. So any of the methodologies used in this paper, could potentially be employed to identify vulnerable municipalities for another province. 
Municipality-wise survey is a small scale survey and there is scope for detail studies which could be very useful for planning to development. This study will help to build the distribution of vulnerable municipalities in Malaga province which is important for hazard management and thus to identify the socio-economically vulnerable community.

\section{Acknowledgements}

This work take part of the project PID2019-106834RB-I00 “Prototipo Cloud de Evaluación de Riesgos a Través de la Integración Espacial de Geodatos (Grid Multiescalares) y Clientes Web (Dashboard) para su Gestión y Medidas de Adapta".

\section{Conflicts of interest and authorship statement}

The authors declare no conflict of interest.

Author Contributions:

- Introduction, data gathering, methodology, calculation, result analysis, conclusion: Sumita Gayen.

- Conceptualization, introduction, mapping, discussion and supervision: Ismael Vallejo Villalta.

- Conceptualization, introduction, methodology, result analysis: Sk. Mafizul Haque.

\section{REFERENCES}

Ahmad, H. F., Bhat, M. S., Alam, A. \& Ahmad, S. (2016). Flood hazard zonation and vulnerability assessment of Greater Srinagar, J\&K, India. Int. J. Adv. Res., 4(12), 1679-1690. http://dx.doi.org/10.21474/IJAR01/2570

Aksha, S. K., Juran, L., Resler, L. M. \& Zhang, Y. (2019). An analysis of social vulnerability to natural hazards in Nepal using a modified social vulnerability index. Int J Disaster Risk Sci., 10, 103-116. https://doi.org/10.1007/s13753-018-0192-7

André, G. (2012). Natural hazard mapping across the world. A comparative study between a social approach and an economic approach to vulnerability. Cybergeo: European Journal of Geography. https://doi.org/10.4000/cybergeo.25297

Armenakis, C., Du, E. X., Natesan, S., Persad, R. A. \& Zhang Y. (2017). Flood risk assessment in urban areas based on spatial analytics and social factors. Geosciences, 7(4), 123. https://doi.org/10.3390/geosciences7040123

Ayuso, J. L., Ayuso-Ruiz, P, García-Marín, A. P., Estévez, J. \& Taguas, E. V. (2015). Local analysis of the characteristics and frequency of extreme droughts in Málaga using the SPI (Standardized Precipitation Index). 17th International Congress on Project Management and Engineering Logroño, 17-19th July 2013 (pp. 881-894). http://dx.doi.org/10.1007/978-3319-12754-5_13

Balica, S.F., Douben, N. \& Wright, N.G. (2009). Flood vulnerability indices at varying spatial scales. Water Science \& Technology, 60(10). https://doi.org/10.2166/wst.2009.183

Barrionuevo, J. F. S. \& Perles Roselló, M. J. (2017). Methodology for vulnerability mapping of the territory against the risk of flood related to assistance systems. Application to bajo Guadalhorse flood area. Geography Papers, 63. http:// dx.doi.org/10.6018/geografia/2017/307051

Beccari, B. (2016). A comparative analysis of disaster risk, vulnerability and resilience composite indicators. PLOS Currents Disasters, 14(1). https://doi.org/10.1371/currents.dis.453df025e34b682e9737f95070f9b970

Birkmann, J., Cardona, O.D., Carreño, M.L., Barbat, A.H., Pelling, M., Schneiderbauer, S., Kienberger, S., Keiler, M., Alexander, D., Zeil, P. \& Welle, T. (2013). Framing vulnerability, risk and societal responses: the MOVE framework. Nat Hazards, 67, 193-211. https://doi.org/10.1007/s11069-013-0558-5

Blaikie, P., Cannon, T., Davis, I. \& Wisner, B. (1994). At risk: natural hazards, people vulnerability and disasters. 1st edition. Routledge.

Bukvic, A., Rohat, G., Apotsos, A. \& de Sherbinin, A. (2020). A systematic review of coastal vulnerability mapping. Sustainability, 12, 2822. https://doi.org/10.3390/su12072822 
Burton, C. G. (2010). Social vulnerability and hurricane impact modeling. Nat. Hazards Rev.,1182, 58-68. https://doi. org/10.1061/(ASCE)1527-6988(2010)11:2(58)

Burton, I., Kates, R. W. \& White, G. F. (1978). The environment as hazard. Oxford University Press.

CAF (2014). Vulnerability index to climate change in the Latin American and Caribbean Region. Corporación Andina de Fomento. Development Bank of Latin America. 206 p.

Caliskan, S., Taubenböck, H., Hinz, S. \& Roth A. (2006). Earthquake vulnerability indicators and vulnerability assessment using remote sensing, Istanbul. 1st EARSeL Workshop of the SIG Urban Remote Sensing. Humboldt-Universität zu Berlin, Germany. https://www.researchgate.net/publication/224798942

Cannon, T., Twigg, J. \& Rowell, J. (2003). Social vulnerability, sustainable livelihoods and disasters. Report to DFID Conflict and Humanitarian Assistance Department (CHAD) and Sustainable Livelihoods Support Office. https://www.eldis.org/ document/A21628

Cardona, 0. D. (2003). The need for rethinking the concepts of vulnerability and risk from a holistic perspective: A necessary review and criticism for effective risk management. In Bankoff, G. Frerks, D. Hilhorst (ed.) Mapping Vulnerability: Disasters, Development and People, Chapter 3. Earthscan Publishers.

Chakraborty, J., Tobin, G. A. \& Montz, B. E. (2005). Population evacuation: assessing spatial variability in geophysical risk and social vulnerability to natural hazards. Natural Hazards Review, 6(1), 23-33. https://doi.org/10.1061/(ASCE)15276988(2005)6:1(23)

Chen, W., Cutter, S. L., Emrich, C. T. \& Shi, P. (2013). Measuring social vulnerability to natural hazards in the Yangtze River delta region, China. Int. J. Disaster Risk Sci., 4(4), 169-181. https://link.springer.com/content/pdf/10.1007/s13753013-0018-6.pdf

Contreras, D., Chamorro, A. \& Wilkinson, S. (2020). Review article: The spatial dimension in the assessment of urban socio-economic vulnerability related to geohazards. Nat. Hazards Earth Syst. Sci., 20, 1663-1687. https://doi. org/10.5194/nhess-20-1663-2020

Copeland, V. C. \& Snyder, K. (2011). Barriers to mental health treatment services for low-income African American women whose children receive behavioral health services: An ethnographic investigation. Social Work in Public Health, 26(1), 78-95. https://doi.org/10.1080/10911350903341036

Cutter, S. L., Boruff, B. J. \& Shirley, W. L. (2003). Social vulnerability to environmental hazards. Social Science Quarterly, 84(2), 242-261. https://doi.org/10.1111/1540-6237.8402002

Cutter, S. L., Burton, C. G. \& Emrich, C. T. (2010). Disaster resilience indicators for benchmarking baseline conditions. Journal of Homeland Security and Emergency Management, 7(1), 51. https://doi.org/10.2202/1547-7355.1732

de Mello Rezende, G. B. (2016). Social vulnerability index: A methodological proposal for application in the cities of Barra do Garcas-MT, Pontal Do Araguaia-MT and Aragarcas_GO, Brazil. Open Journal of Social Sciences, 4, 32-45. https://file.scirp.org/Html/4-1761151_72561.htm

de Oliveira Mendes, J. M. (2009). Social vulnerability indexes as planning tools: beyond the preparedness paradigm. Journal of Risk Research, 12(1), 43-58. https://doi.org/10.1080/13669870802447962

Diaz-Sarachaga, J. M. \& Jato-Espino, D. (2020). Analysis of vulnerability assessment frameworks and methodologies in urban areas. Natural Hazards, 100, 437-457. https://doi.org/10.1007/s11069-019-03805-y

Djalante, R. (2019). Key assessments from the IPCC special report on global warming of $1.5^{\circ} \mathrm{C}$ and the implications for the Sendai framework for disaster risk reduction. Progress in Disaster Science, 1. https://doi.org/10.1016/j.pdisas.2019.100001

Duzgun, H. S. B., Yucemen, M. S., Kalaycioglu, H. S., Celik, K., Kemec, S., Ertugay, K. \& Deniz, A. (2011). An integrated earthquake vulnerability assessment framework for an urban area. Nat Hazards, 59, 917. https://doi.org/10.1007/ s11069-011-9808-6

Dwyer, A., Zoppou, C., Nielsen, O., Day, S. \& Roberts, S. (2004). Quantifying social vulnerability: A methodology for identifying those at risk to natural hazards. Geoscience Australia Record, 14. http://www.geosci.usyd.edu.au/users/prey/ Teaching/Geos-2111GIS/Ref/GA4267-IdentifyingRisks.pdf

EEA (2018). Unequal exposure and unequal impacts: social vulnerability to air pollution, noise and extreme temperatures in Europe. European Environment Agency. EEA Report No 22. https://doi.org/10.2800/324183

Emrich, C. T. \& Cutter, S. L. (2011). Social vulnerability to climate-sensitive hazards in the Southern United States. Weather, Climate, and Society, 3 (3), 193-208. https://doi.org/10.1175/2011WCAS1092.1 
Evans, J. M., Hauer, M., Hardy, D. \& Pippin, J. S. (2014). Assessing social vulnerability using "SoVI-Lite": A demonstration study at Glynn County, GA. Carl Vinson Institute of Government, University of Georgia. https://doi.org/10.13140/2.1.2329.3765

Flanagan, B. E., Gregory, E. W., Hallisey, E. J., Heitgerd, J. L. \& Lewis, B. (2011). A social vulnerability index for disaster management. Journal of Homeland Security and Emergency Management, 8(1), 3. https://svi.cdc.gov/A\%20Social\%20 Vulnerability\%20Index\%20for\%20Disaster\%20Management.pdf

Fekete, A. (2009). Validation of a social vulnerability index in context to river-floods in Germany. Nat. Hazards Earth Syst. Sci., 9, 393-403. https://doi.org/10.5194/nhess-9-393-2009

Fekete, A. (2018). Social vulnerability change assessment: monitoring longitudinal demographic indicators of disaster risk in Germany from 2005 to 2015. Natural Hazards, 95, 585-614. https://doi.org/10.1007/s11069-018-3506-6

Frigerio, I., Carnelli, F., Cabinio, M. \& Amicis, M. D. (2018). Spatiotemporal pattern of social vulnerability in Italy. Int J Disaster Risk Sci., 9(2), 249-262. https://doi.org/10.1007/s13753-018-0168-7

Gallegos Reina, A., (2013). Cuantificación y distribución cartográfica de la generación de escorrentía y sedimentos en la provincia de Málaga. Baetica. Estudios de Arte, Geografía e Historia, 35, 57-74. http://hdl.handle.net/10630/7823

Gallegos Reina, A. \& Perles Roselló, M. J. (2019). Relaciones entre los cambios en los usos del suelo y el incremento de los riesgos de inundabilidad y erosión: análisis diacrónico en la provincia de Málaga (1957-2007). Boletín de La Asociación de Geógrafos Españoles, 81, 2740, 1-38. http://dx.doi.org/10.21138/bage.2740

Gayen, S., Villalta, I. V. \& Haque, S. K. (2019). Earthquake hazard scenario and seismic micro-zoning assessment in Málaga province of Spain. European Journal of Geography, 10(1), 117-133. http://www.eurogeographyjournal.eu/articles/0810012019.pdf

Gayen, S., Villalta, I. V. \& Haque, S. M. (2020). Comparative Social Vulnerability Assessment in Purba Medinipur District, West Bengal, India. European Journal of Geography, 11(1), 093-107. https://doi.org/10.48088/ejg.S.gay.11.1.93.107

Ge, Y., Dou, W. and Dai, J. (2017). A new approach to identify social vulnerability to climate change in the Yangtze River delta. Sustainability, 9(12), 2236. https://doi.org/10.3390/su9122236

Girasole, E. G., and Cannatella, D. (2017). Social vulnerability to natural hazards in urban systems. An application in Santo Domingo (Dominican Republic). Sustainability, 9(11), 2043. https://doi.org/10.3390/su9112043

Gu, D. (2019). Exposure and vulnerability to natural disasters for world's cities. United Nations, Department of Economics and Social Affairs, Population Division, Technical Paper No. 4. https://www.un.org/en/development/desa/population/ publications/pdf/technical/TP2019-4.pdf

Guillard-Gonçalves, C., Cutter, S. L., Emrich, C. T. \& Zêzere, J. L. (2015). Application of social vulnerability index (SoVI) and delineation of natural risk zones in Greater Lisbon, Portugal. Journal of Risk Research, 18(5), 651-674. https://doi.or g/10.1080/13669877.2014.910689

Gutiérrez-Hernández, O., Senciales-González, J. M. \& García, L. V. (2015). Los incendios forestales en Andalucía: investigación exploratoria y modelos explicativos. FLAMMA, 6(3), 144-148. https://www.academia.edu/26652060/Los_incendios_forestales_en_Andaluc\%C3\%ADa_investigaci\%C3\%B3n_exploratoria_y_modelos_explicativos_Wildfires_in_Andalusia_Spain_from_exploratory_research_to_explanatory_models

Hoffmann, R. \& Blecha, D. (2020). Education and disaster vulnerability in Southeast Asia: Evidence and policy implications. Sustainability, 12, 1401. https://doi.org/10.3390/su12041401

Holand, I. S., Lujala, P. \& Rød, J. K. (2011). Social vulnerability assessment for Norway: A quantitative approach. Norsk Geografisk Tidsskrift - Norwegian Journal of Geography, 65(1), 1-17. https://doi.org/10.1080/00291951.2010.550167

Insua-Arévalo, J. M., Martínez-Díaz, J. J., García-Mayordomo, J. \& Martín-González, F. (2012). Active tectonics in the Malaga Basin: evidences from morphotectonic markers (Western Betic Cordillera, Spain). Journal of Iberian Geology, 38 (1), 175-190. http://dx.doi.org/10.5209/rev_JIGE.2012.v38.n1.39212

Kablan, M.K.A., Dongo, K. \& Coulibaly, M. (2017). Assessment of social vulnerability to flood in Urban Côte d'Ivoire Using the MOVE Framework. Water, 9(4), 292. https://doi.org/10.3390/w9040292

Kalaycıoğlu, S., Rittersberger-Tılıç, H., Çelik, K. \& Güneş, F. (2006). Integrated natural disaster risk assessment: The socio-economic dimension of earthquake risk in the urban area. Geohazards- Engineering Conferences International. https://dc.engconfintl.org/cgi/viewcontent.cgi?article=1013\&context=geohazards

Khan, F. A. \& Salman, A. (2012). A simple human vulnerability index to climate change hazards for Pakistan. Int. J. Disaster Risk Sci., 3(3), 163-176. https://link.springer.com/content/pdf/10.1007/s13753-012-0017-z.pdf 
Kirby, R. H. (2015). Measuring social vulnerability to environmental hazards in the Dutch Province of Zeeland. LSU Master's Theses. 3800. https://digitalcommons.Isu.edu/gradschool_theses/3800

Koks, E. E., Jongman, B., Husby, T. G. \& Botzen, W. J. W. (2015). Combining hazard, exposure and social vulnerability to provide lessons for flood risk management. Environmental Science \& Policy, 47, 42-52. https://doi.org/10.1016/j. envsci.2014.10.013

Kuhlicke, C., Scolobig, A., Tapsell, S., Steinfu“ hrer, A. \& Marchi, B. D. (2011). Contextualizing social vulnerability: findings from case studies across Europe. Nat Hazards, 58, 789-810. https://link.springer.com/article/10.1007/s11069-0119751-6

Lee, Y. J. (2014). Social vulnerability indicators as a sustainable planning tool. Environmental Impact Assessment Review, 44, 31-42. https://doi.org/10.1016/j.eiar.2013.08.002

Lowe, D., Ebi, K. L. \& Forsberg, B. (2013). Factors increasing vulnerability to health effects before, during and after floods. Int. J. Environ. Res. public Health, 10(12), 7015-7067. https://doi.org/10.3390/ijerph10127015

Mavhura, E., Manyena, B. \& Collins, A. E. (2017). An approach for measuring social vulnerability in context: The case of flood hazards in Muzarabani district, Zimbabwe. Geoforum, 86, 103-117. https://doi.org/10.1016/j.geoforum.2017.09.008

Madeca (2017). Estudio sobre la problemática por el riesgo de inundaciones en la provincia de Málaga. Madeca. Page, 112.

Morales, A. P., Hervás, F. N. \& Rogel, Y. A. (2016). Propuesta metodológica para la evaluación de la vulnerabilidad social en poblaciones afectadas por el peligro de inundación: el caso de Águilas (Murcia, sureste). Documents d'Anàlisi Geogràfica, 62(1). https://doi.org/10.5565/rev/dag.242

Morrow, B. H. (1999). Identifying and mapping community vulnerability. Disasters, 23(1), 1-18. https://doi.org/10.1111/14677717.00102

Muhadi, N. A., Abdullah, A. F., Bejo, S. K., Mahadi, M. R. \& Mijic, A. (2020). The use of LiDAR-Derived DEM in flood applications: A review. Remote Sens., 12 (14), 2308. https://doi.org/10.3390/rs12142308

Müller, A., Reiter, J. \& Weiland, U. (2011). Assessment of urban vulnerability towards floods using an indicator-based approach - a case study for Santiago de Chile. Nat. Hazards Earth Syst. Sci., 11(8), 2107-2123. https://doi.org/10.5194/ nhess-11-2107-2011

Navarro, D., Vallejo, I. \& Navarro, M. (2020). Análisis de la vulnerabilidad social a los riesgos naturales mediante técnicas estadísticas multivariantes. Investigaciones Geográficas, 74, 29-49. https://doi.org/10.14198/INGEO2020.NVN

Papathoma-Köhle, M., Schlögl, M. \& Fuchs, S. (2019). Vulnerability indicators for natural hazards: an innovative selection and weighting approach. Sci Rep, 9, 15026. https://doi.org/10.1038/s41598-019-50257-2

Pencheon, D. (2007). The good indicators guide: Understanding how to use and choose indicators. NHS Institute for Innovation and Improvement, Coventry, UK. https://www.england.nhs.uk/improvement-hub/wp-content/uploads/ sites/44/2017/11/The-Good-Indicators-Guide.pdf

Perles-Roselló, M. J. (2010). Apuntes para la evaluación de la vulnerabilidad social frente al riesgo de inundación. Baetica. Estudios de Arte, Geografía e Historia, 32, 67-87. https://doi.org/10.24310/BAETICA.2010.v0i32.133

Perles Roselló, M.J., Sortino Barrionuevo, J.F. \& Cantarero Prados, F. (2017). Cartografía de la vulnerabilidad del territorio frente al riesgo de inundación. Propuesta adaptada a la directiva europea de inundaciones ynormativas derivadas. Boletín de la Asociación de Geógrafos Españoles, 75. 341-372. https://doi.org/10.21138/bage.2504

Pharr, J. R., Moonie, S. \& Bungum, T. J. (2012). The impact of unemployment on mental and physical health, access to health care and health risk behaviors. ISRN Public Health, 483432. https://doi.org/10.5402/2012/483432

Prieto, A., Díaz, M. P., Ojeda J. \& Álvarez, J. I. (2017). Tasas de erosión en las playas de Andalucía: el efecto de infraestructuras costeras longitudinales y urbanización. Geotemas, 243-246. https://www.researchgate.net/publication/324720318_Tasas_de_erosion_en_las_playas_de_Andalucia_el_efecto_de_infraestructuras_costeras_longitudinales_y_urbanizacion

Ran, J., MacGillivray, B. H., Gong, Y. \& Hales, T. C. (2020). The application of frameworks for measuring social vulnerability and resilience to geophysical hazards within developing countries: A systematic review and narrative synthesis. Science of the Total Environment, 711, 134486. https://doi.org/10.1016/j.scitotenv.2019.134486

Reid, C. E., O'Neill, M. S., Gronlund, C. J., Brines, S. J., Brown, D. G., Diez-Roux, A. V. \& Schwartz, J. (2009). Mapping community determinants of heat vulnerability. Environmental Health Perspectives, 117(11), 1730-1736. https://doi. org/10.1289/ehp.0900683

Rodríguez, H., Quarantelli, E. L. \& Dynes, R. R. (2007). Handbook of Disaster Research. Springer. 
Sajjad, H. \& Jain, P. (2014). Assessment of socio-economic vulnerabilities among urban migrants in South-East Delhi, India. Journal of Studies in Social Sciences, 7(1), 65-81. https://infinitypress.info/index.php/jsss/article/view/652

Sánchez, D. S. \& Del Moral, L. (2014). Tres décadas de política de aguas en Andalucía. Análisis de procesos y perspectiva territorial. Cuadernos Geográficos, 53(1), 36-67. http://hdl.handle.net/11441/43624

Sen, A. (1998). Mortality as an indicator of economic success and failure. The Economic Journal, 108 (446), 1-25. https:// doi.org/10.1111/1468-0297.00270

Tali, M.G., Naeimi, A. \& Esfandiary, M. (2016). Physical development of Arak City applying natural indicators. European Journal of Geography, 7(3), 99 - 110. http://www.eurogeographyjournal.eu/articles/7.PHYSICAL\%20DEVELOPMENT\%20 OF\%20ARAK\%20CITY\%20APPLYING\%20NATURAL\%20INDICATORS.pdf

Tapsell, S., Tunstall, S., Green, C. \& Fernández-Bilbao, A. (2005). Task 11 social indicator set. FLOODsite Project Report, T11-5-01. http://www.floodsite.net/html/partner_area/project_docs/M11.1_Indicator-set_7-05.pdf

Tascón-González, L., Ferrer-Julià, M., Ruiz, M. \& García-Meléndez, E. (2020). Social vulnerability assessment for flood risk analysis. Water, 12(2), 558. https://doi.org/10.3390/w12020558

Thomas, V. \& López, R., (2015). Global increase in climate-related disasters. Asian Development Bank Economics Working Paper Series No. 466. http://dx.doi.org/10.2139/ssrn.2709331

Török, I. (2018). Qualitative assessment of social vulnerability to flood hazards in Romania. Sustainability, 10, 3780. https://doi.org/10.3390/su10103780

UN (2016). Report of the open-ended intergovernmental expert working group on indicators and terminology relating to disaster risk reduction. Prevention web, UNDRR, Geneva, Switzerland.

Wamsler, C., Brink, E. \& Rantala, O. (2012). Climate change, adaptation, and formal education: The role of schooling for increasing societies' adaptive capacities in El Salvador and Brazil. Ecology \& Society, 17(2), 2. https://doi.org/10.5751/ ES-04645-170202

Weichselgartner, J. (2001). Disaster mitigation: The concept of vulnerability revisited. Disaster Prevention and Management, 10(2), 85-95. https://doi.org/10.1108/09653560110388609

Wisner, B., Blaikie, P., Cannon, T. \& Davis, I. (2004). At risk: natural hazards, people's vulnerability and disasters. Second edition, Routledge.

Wu, S. Y., Yarnal, B. \& Fisher, A. (2002). Vulnerability of coastal communities to sea-level rise: A case study of Cape May County, New Jersey, USA. Climate Research, 22, 255-270. https://www.int-res.com/abstracts/cr/v22/n3/p255-270/

Yan, X. \& Li, X. (2016). Evaluation on social vulnerability to natural disasters. The Anthropologist, 24(2), 570-580.

https://doi.org/10.1080/09720073.2016.11892051

Yang, S., He, S., Du, J. \& Sun, X. (2014). Screening of social vulnerability to natural hazards in China. Nat Hazards, 76, 1-18. https://doi.org/10.1007/s11069-014-1225-1

Yoon, D. K. (2012). Assessment of social vulnerability to natural disasters: a comparative study. Nat. Hazards, 63, 823-843. https://doi.org/10.1007/s11069-012-0189-2

Zhang, N. \& Huang, H. (2013). Social vulnerability for public safety: A case study of Beijing, China. Chinese Science Bulletin, 58 (19), 2387-2394. https://doi.org/10.1007/s11434-013-5835-x

Žurovec, O., C`adro, S. \& Sitaula, B. K. (2017). Quantitative assessment of vulnerability to climate change in rural municipalities of Bosnia and Herzegovina. Sustainability, 9(7), 1208. https://doi.org/10.3390/su9071208 